\title{
Plastics: Unger and Ackerman on Transformation
}

\author{
Lawrence Lessig
}

Along one front of the battle between Critical Legal scholars ${ }^{1}$ and others is a struggle over the nature of social transformation, a debate over the ease with which a society should be able to change itself from what it is to something else. On one side of this debate, the radical "crits" champion "plasticity," the claim that social and political structures should be easily transformed; ${ }^{3}$ on the other, opponents argue that some constituting structures (at least) must remain rigid, removed from the agenda of ordinary political action. ${ }^{4}$ Between these two extremes stands an apparently wide gulf, unbridged, and perhaps unbridgeable, by theorists of either side.

But it is just not clear how wide a gap this gulf really is, or how radically different we should consider the "radicals" to be. For much of the debate over social transformation appears to rest upon a confusion, engendered in part by an ambiguity in the meaning of "transformation" itself. This ambiguity leads rivals to overstate their disagreements, obscuring much of what may be in common among them. By examining the works of two of these rivals-Bruce Ackerman ${ }^{\mathbf{s}}$ and Roberto Unger ${ }^{6}$ - this Note

1. For a helpful summary of "the movement's" contributions, see M. KelMan, A Guide to Crmcal Legal Studies (1987). See also A Bibliography of Critical Legal Studies, 94 Yale L.J. 461 (1984).

2. One sense of "plasticity" is the capacity of social structures, and therefore social worlds, to be formed and reformed; this is the sense of "constructivism" discussed below. See infra text accompanying notes 29-37. Another sense, that emphasized by this Note, focuses not on the capacity of social structures to be formed or reformed, but on the ease with which they can be formed and reformed. See infra text accompanying notes 38-50.

3. As Roberto Unger claims, "[t]he revolutionary ideologies of liberalism, socialism, and communism all seek to develop forms of empowerment through the subversion of rigid roles and hierarchies and through the subjection of social life to the transforming will." R. UNGER, FALSE NECESSITY: Anti-NeCessitarian Social Theory in The Service of Radical Democracy 296 (1987) [hereinafter FAISE NECESSITY]. For an argument by a non-Crit suggesting that existing constitutional structures are more plastic than we think, see Amar, Philadelphia Revisited: Amending the Constitution Outside Article V, 55 U. GHI. L. Rev. 1043 (1988).

4. Rather than making constitutional structures universally more plastic, Bruce Ackerman suggests that the failure of the modern lawyer is her refusal to distinguish between ordinary and extraordinary structure-transforming action, "between the constitutional conclusions reached by a mobilized citizenry and the ordinary outcomes of normal politics." Ackerman, The Storrs Lectures: Discovering the Constitution, 93 YALE L.J. 1013, 1035 (1984).

5. The primary works by Ackerman addressed in this Note include B. Ackerman, Discovering THE Constrtution (forthcoming) [hereinafter Discovering]; B. Ackerman, Reconstructing American Law (1984) [hereinafter Reconstructing]; B. ACkerman, Social Justice in the 
aims to erase this confusion, and thereby draw together the opposing sides. $^{7}$

The confusion is undone by a theory of social meaning, held in common between these two rivals. With this theory, two types of "transformation" will be distinguished, the case for plasticity turning upon which "transformation" is at issue. As this Note argues, under one conception, both Ackerman and Unger can accept plasticity; under the other, with differing emphases, both must caution against its unconditioned embrace. This differing emphasis, then, maps the distance between these two rivals. However wide the scope, this Note argues it is far more narrow than the rhetoric suggests. Once we understand what unites these rivals, the differences that remain no longer overwhelm.

\section{Gommon Ground}

Before we can explore the differences dividing Unger and Ackerman, we must first understand the common ground they share. ${ }^{8}$ Despite their apparent conflict, a philosophical theory ${ }^{\ominus}$ unites Ackerman and Unger, a theory touching the modalities of social meaning, ${ }^{10}$ the necessary and pos-

Liberal State (1980) [hereinafter Social Justice]; B. Ackerman, Private Property and the Constitution (1977) [hereinafter PROPERTY]; Ackerman, supra note 4.

6. This Note focuses primarily on Unger's more recent works, including R. UNGER, THE CRITICal Legal Studies Movement (1986) [hereinafter Critical]; R. UNGer, Passion: AN Essay ON Personality (1984) [hereinafter Passion]; R. Unger, Politics, A Work in Constructive SoCIAL, Theory ( 3 volumes, including Social Theory: ITs Situation and ITs TaSk (1987) [hereinafter Social Theory], False Necessity, supra note 3, Plastictry iNTo Power (1987) [hereinafter PLAsticity]). As many have noted, these works rely upon a philosophy fundamentally different from Unger's earlier works, KNOWLEDGE AND Polrtics (1975), and LAW IN MODERN SOCIETY (1976). E.g., Collins, Roberto Unger and the Critical Legal Studies Movement, 14 J.L. \& Soc'y 387, 395 (1987) (noting change in epistemological assumptions); West, CLS and a Liberal Critic, 97 YALE L.J. 757, 758 (1988) (same); Boyle, Modernist Social Theory: Roberto Unger's Passion (Book Review), 98 Harv. L. Rev. 1066, 1079 (1985) (same); Simon, Social Theory and Political Practice: Unger's Brazilian Journalism, 81 Nw. U.L. Rev. 832, 866 (1987) (noting change in philosophical approach). Unger himself notes the shift, KNowledge AND Polrtrcs 337-41 (1984). But despite this warning, some have missed the shift. See, e.g., Ewald, Unger's Philosophy: A Critical Legal Study, 97 YALE L.J. 665, 668, 673 n.38, 729 (1988) (critiquing range of Unger's work as if no shift had occurred); Note, 'Round and 'Round the Bramble Bush: From Legal Realism to Critical Legal Scholarship, 95 HaRv. L. Rev. 1669, 1679 n.70 (1982) (earlier work "leads into" the later); Pateman, Book Review, 96 ErHics 422, 422 (1986) (linking earlier work and Passion).

7. For discussions of their rivalry, see Cohen, High-Tech Justice, 38 STAN. L. REv. 919, 924 (1986) (reviewing B. ACKERMAN, RzCONSTRUCTING AMERICAN LAw); Hutchinson, From Cultural Construction to Historical Deconstruction, 94 YALE L.J. 209, 214, 235 n.140 (1984) (reviewing J.B. White, When Words Lose Their Meaning); Teachout, Worlds Beyond Theory, 83 Mich. L. REV. 849, 877-78 (1985) (reviewing same).

8. It is the work of Renford Bambrough which motivates this search for common ground between these combatants. As Bambrough suggests, it is a "necessary truth that even a conflict of opinions can be found only where there is a community of understanding." Bambrough, The Scope of Reason: An Epistle to the Persians, in Objectivity and Cultural Divergence 195, 198 (S.C. Brown ed. 1984).

9. For the purposes of this Note, a question or theory is considered "philosophical" if it engages questions of epistemology or metaphysics. See P. Winch, The IDEA OF A Social SCIENCE 7 (1958); see also Yablon, Law and Metaphysics, 96 YALE L.J. 613, 616 (1987) (discussing relationship of law to philosophy).

10. Throughout this Note, "social meaning" refers to the contextual meaning of the full range of 
sible of social life. Two dimensions of this theory are important for the argument of this Note, "contextuality"11 and "constructivism."12 In the sections that follow, these dimensions are sketched. ${ }^{13}$

\section{A. Contextuality}

It is commonplace that a sentence has meaning by virtue of its use within a context of understanding or expectation, ${ }^{14}$ and a small step from

social artifacts, conveyed by their role in social life. This population includes obvious meaningartifacts, such as language and gesture, as well as others less obvious, such as legal concepts, modes of production, institutions, and governments. See infra note 15 (discussing tokens).

11. Contextuality is a motif running through a wide range of theorists, both in philosophy, see generally R. RoRty, Consequences of PRAGmatism (1982); P. Winch, supra note 9; L. Wittgenstein, ON Certainty (D. Paul \& G.E.M. Anscombe trans. 1979); L. WittGenstein, Philosophical Investigations (G.E.M. Anscombe trans. 2d ed. 1958); L. Wittgenstein, ZetTEL (G.E.M. Anscombe trans. 2d ed. 1981), and social and legal theory, see generally G. GEERTZ, THE INTERPRETATION OF CULtures (1973); C. GeERTZ, Local KNOWLEDGE (1983); C. TAYLOR, Philosophy and the Human Sciences (1985); Cover, The Supreme Court, 1982 Term-Foreword: Nomos and Narrative, 97 HARv. L. REv. 4, 5 n.7 (1983) (discussing thick contextuality of moral discourse); Fiss, Objectivity and Interpretation, 34 Stan. L. REv. 739, 745 (1982) (discussing role of interpretative community in anchoring objective interpretation).

While Unger distinguishes his position from Wittgenstein's, see Passion, supra note 6, at 11; SocIAL THEORY, supra note 6 , at 226, his disclaimer goes to the possibility of constructivism, rather than the fact of contextuality, and is in any case a misreading of Wittgenstein. See S. LoviBond, REALISM AND IMAGINATION IN ETHICS 125-28 (1983) (arguing Wittgensteinian contextualism allows possibility of construction and critique); Cornell, "Convention" and Critique, 7 CARdozo L. Rev. 679, 688 (1986) (implying same).

12. Like contextuality, constructivism refers to no school in particular, but rather to a theme regarding the nature of social meaning. That our social world is constructed is not a new idea. For its chief modern pronouncement, see P. Berger \& T. Luckmann, The Social Construction of REALITY 49 (1967) ("While it is possible to say that man has a nature, it is more significant to say that man constructs his own nature, or more simply, that man produces himself."). See also D. Bloor, Wittgenstein: A Social Theory of KNoWledge (1983); C. GeerTZ, The INTERPRETATION OF CULTURES, supra note 11, at 5 ("[M]an is an animal suspended in webs of significance he himself has spun . . . "); N. Goodman, WAys of WorLdmakING 7 (1978) ("With false hope of a firm foundation gone, with the world displaced by worlds that are but versions, with substance dissolved into function, and with the given acknowledged as taken, we face the questions how worlds are made, tested, and known."); R. RORTY, supra note 11, at xxxix ("Can we see ourselves as never encountering reality except under a chosen description ... making worlds rather than finding them?"); J.B. White, When Words Lose Their MeAning 273 (1984) ("[The law is an] open hearing in which one point of view, one construction of language and reality, is tested against another."); B. WhORF, LANGUAGE, Thought, AND REALITY 207-19 (1956); Cornell, supra note 11, at $690-91$ (Wittgenstein perceiving social reality as constituted by language); Cover, supra note 11; Sapir, Conceptual Categories in Primitive Languages, in Language in Culture and Society 128, 128 (D. Hymes ed. 1964).

13. While the picture which will emerge is of necessity only a caricature of a theory far more complex, this sketch will suffice for the arguments that follow. The theory of meaning outlined below simplifies along at least two dimensions. First, the theory ignores the role of the interpreter; second, it ignores problems of indeterminacy in meaning. See S. FISH, Is THERE A TEXT IN THrs CLAss? 1-17, 147-73 (1980). These issues are crucial to any fully developed understanding of meaning, but must be bypassed for the purposes of this Note.

14. See L. Wittgenstein, Philoosophical Investigations, supra note 11, at II 43 \& passim; C. TAYLoR, Interpretation and the Sciences of Man, in PHILOSOPHY aNd THE Human Sctences 33-34 (1985) ("[V]ocabulary . . . is grounded in the shape of social practice . . . and would not make sense . . . where this range of social practices did not exist."); Stroup, Law and Language: Cardozo's Jurisprudence and Wittgenstein's Philosophy, 18 VAL. U.L. REv. 331, 350 (1984) ("Language, then, derives its meaning from its use in a context, in concrete situations."). 
this commonplace to the more general proposition that tokens ${ }^{15}$ of meaning have meaning only by virtue of contexts or structures background. ${ }^{16}$ Meaning is a function of both token and context. ${ }^{17}$ Two aspects of this "contextuality" are relevant to this Note.

The first aspect is the core nature of "context" itself. A context is composed of structures of understanding, ${ }^{18}$ a scaffolding within which concepts exist. ${ }^{19}$ Meaning is conditioned upon context, and thus conditioned ${ }^{20}$ upon the structures that compose this context. These structures, often invisible to ordinary analysis, ${ }^{21}$ include the full range of patterned expectations and understandings, from styles of fashion, to norms of etiquette, to conventions of speech, to rules of law. ${ }^{22}$ They infect every activity, "secrete"23 their own norms. Together they make up the status quo, ${ }^{24}$ to be justified if the status quo is to be justified. ${ }^{25}$ Contextuality teaches us to

15. "Token" refers to a symbol of meaning: a statement, a wink, an institution, a practice, an action, an inaction. Under this broad understanding, then, token can refer either to the literal words of a text, for example, or, in the context of a statute, to the application of those words in the particular context. This distinction, between the words and their application, will be crucial below. See infra note 78 and accompanying text.

16. See Soclal Theory, supra note 6 , at 4. Following Unger, this Note does not distinguish between 'context,' 'structure,' and 'framework.' Id. at 3.

17. "[M]eaning does not reside simply in the words of a text but is a product of linguistic and cultural understandings and experiences ...." R. Posner, The Problems of Jurisprudence 138 (1988) (unpublished manuscript) (footnote omitted). For a discussion of context-dependent intellectual movements, see Boyle, supra note 6 , at 1067 n.4.

18. A context includes "[t]he institutional and imaginative frameworks of social life [that] supply the basis on which people define and reconcile interests, identify and solve problems." Social THEORY, supra note 6, at 4. See also id. at 3 (defining context), 151 (same); FALSE NecessitY, supra note 3, at 58-61 (same). It comprises the "stock forms of legal, moral, and ideological argument," id. at 100 , as well as other noninstitutional or imaginative components, see id. at 100 , including "possible and desirable forms of human association ...." Id. at 58. It is reproduced in the "banal activities of daily life," see Social Theory, supra note 6, at 152, and exists "in the sense that people cannot easily disturb it in the course of their ordinary activities." FALSE NECESSITY, supra note 3, at 61.

19. "It is as if our concepts involved a scaffolding of facts." " L. WITTGENSTEIN, ZETTEL, supra note 11 , at I 350 .

20. See Social Theory, supra note 6 , at 19.

21. "The task, then, is to deny any fundamental power structure the priceless advantage of invisibility," SocIAL Justice, supra note 5 , at 19 , an invisibility issuing from the blindness to the conditional nature of social meaning. Cf. B. WHORF, supra note 12, at 211 ("[T] he phenomena of a language are to its own speakers largely of a background character and so are outside . . . critical consciousness and control .....").

22. See, e.g., Cover, supra note 11, at 4 ("We inhabit a nomos-a normative universe. We constantly create and maintain a world of right and wrong, of lawful and unlawful, of valid and void.").

23. C. Taylor, Neutrality in Political Science, in Philosophy and the Human Sciences, supra note 11 , at 90 .

24. For an especially sensitive analysis of the place of the status quo in legal thinking, see Sunstein, Lochner's Legacy, 87 ColuM. L. REv. 873 (1987).

25. See Reconstructing, supra note 5, at 54 ("lawyer cannot simply assume the legitimacy of the ongoing structure of activities"); Ackerman, Four Questions for Legal Theory, in Nomos XXII: Property 351, 370 (J.R. Pennock \& J.W. Chapman eds. 1980) (increasing need for courts to examine ideals of status quo); Cole, Against Literalism, 40 STAN. L. REv. 545, 558 (1988) (reviewing J.B. WhITE, HERACLES' Bow) ("CLS aims to undermine legal doctrine in order to reveal its ideological and legitimating functions, and to force us to question our unreflective acceptance of certain ideological principles."). 
focus upon these structures, to understand their nature so as to understand the nature of the meaning they permit. ${ }^{28}$

The second aspect of contextuality relevant to this Note is the method of analysis contextuality suggests. Since meaning is a function of both token and context, ${ }^{27}$ an analysis of meaning must include an account of each. A change in either can affect meaning; therefore, the meaning of a token is not necessarily preserved simply by keeping the token unchanged. Between two moments of time, contextuality tutors us to track both the change in the token and the change in the context, so as to track the change in meaning.

Ackerman and Unger embrace both aspects of contextuality, and are guided by contextuality throughout their work. ${ }^{28}$ Contextuality is the first aspect of a theory of meaning the rivals share.

\section{B. Constructivism}

Where contextuality identifies the components of social meaning, constructivism ${ }^{29}$ teaches that each element is (at least potentially) under social control: We can change both the tokens of social meaning and the structures that give these tokens their meaning. No structure or routine of social life is either natural or necessary; ${ }^{30}$ each is an artifact, ${ }^{31}$ socially cre-

26. See Cornell, supra note 11 , at 685 ("[M]eaning is revealed in context but not absolutely determined by it."); Fish, Fish v. Fiss, 36 STAN. L. REv. 1325, 1332-39 (1982) ("Interpreters are constrained by their tacit awareness of what is possible and not possible to do, what is and is not a reasonable thing to say, and what will and will not be heard as evidence in a given enterprise ....").

27. As Posner writes, "A normal English speaker does not interpret a message merely by consulting the dictionary definitions of each word . . . . He consults the totality of his relevant experience, which . . . includes . . social practices . . . Meaning depends on context as well as semantics." R. Posner, supra note 17 , at 120 .

28. "The contextual quality of thought is a brute fact." Social Theory, supra note 6, at 19. "Al[t]hough we can transcend our contexts, we cannot pursue any of our ordinary human concerns outside a context." FALSE NECESSITY, supra note 3, at 433. Any meaningful activity or thought is contextual; context is enabling, since constituting all meaningful human activity, but also constraining. Passion, supra note 6 , at 4.

In ReCONSTRUCTING AMERICAN LAw, Ackerman develops a structural account of the facts of legal disputes, see RECONSTRUCTING, supra note 5, at 29, 46-47, aiming thereby to "explicate[] the interpretative frameworks . . . . [in] American legal culture." Id. at 53 n.9. In Private Property AND THE CONSTITUTION, by outlining two such interpretative frameworks, Ackerman untangles the confusion in compensation clause cases. PROPERTY, supra note 5, at 5, 175-76. See also Ackerman, The Structure of Subchapter C: An Anthropological Comment, 87 YALE L.J. 436 (1977) (discussing role of interpretative structures in understanding content of statutory code); $c f$. Cohen, supra note 7 , at 924 ("At first blush, Ackerman's structural account sounds a little like the 'deviationist doctrine' of the critical legal studies movement, which 'commits itself to integrate into standard doctrinal argument the explicit controversy over the right and feasible structure of society, over what the relations among people should be like in the different areas of social activity.' ") (quoting Unger, The Critical Legal Studies Movement, 96 HARv. L. REv. 561, 578 (1983)).

29. Contextuality by itself does not imply constructivism. Other theories have identified structures guiding social life and evolution without suggesting these structures were amenable to human control. Unger identifies two, which he calls naturalism and deep structure (or deep logic) theories. See PASSION, supra note 6, at 5-6; SOCIAL. THEORY, supra note 6, at 23-24, 84-87 (discussing naturalism), 88-96 (discussing deep structure theories).

30. See Social Justice, supra note 5, at 164 (on naturalness of family); S. Lovibond, supra 
ated and socially changed. No superstructure guides social evolution, or at least none that we could not ultimately transform. ${ }^{32}$

To deny constructivism is to betray what Unger calls "false necessity." False necessity is "the ease with which we mistake the constraints imposed by a particular formative context of social life for the inherently psychological, organizational, and economic imperatives of society." revealing the nature of context and constraint, ${ }^{34}$ constructivism uncovers the means by which constraint is remade and context overcome. ${ }^{35}$

The theme of constructivism, then, is the artificial, socially-made, and possible of social life. ${ }^{36}$ Both Ackerman and Unger embrace constructivism, ${ }^{37}$ however differently they may develop it.

note 11 , at 118 (organic connection of language with culture); $i d$. at 117 (Wittgensteinian conception means linguistic world not natural phenomenon, but "a product of our own actions"); id. at 119 (subject only to the constraint of community, "nothing constrains our choice of . . . what linguistic systems to maintain"); Social TheORY, supra note 6, at 145 ("They want to deprive these frameworks or contexts of their aura of higher necessity or authority. Above all, they want to affirm that things can be otherwise.").

31. See False Necessity, supra note 3, at 61 ("[Contexts] are artifacts, and makeshift ones at that, but they are not just factitious entities that cease to exist as soon as people stop taking them seriously."); see also Social THEORY, supra note 6, at 1 (modern social thought viewing society as human artifact); J.B. White, supra note 12, at 26 (same); Cornell, Beyond Tragedy and Complacency, 81 Nw. U.L. REv. 693 (1987) ("Our social world is made, not given."); cf. J.B. White, Heracles' Bow 103 (1985) ("artificial" means only that structures are constructed, not that they are unreal).

32. False Necessity, supra note 3 , at 4, 65-66.

33. Passion, supra note 6, at 14. Marx spoke of something similar:

Hitherto men have constantly made up for themselves false conceptions about themselves, about what they are and what they ought to be. They have arranged their relationships according to their ideas of God, of normal man, etc. The phantoms of their brains have got out of their hands. They, the creators, have bowed down before their creations. Let us liberate them from the chimeras, the ideas, dogmas, imaginary beings under the yoke of which they are pining away.

K. Marx \& F. Engels, The German Idealogy 37 (Lawrence \& Wishart trans. 2d ed. 1974).

34. See FALSE NECESSITY, supra note 3, at 254-55 (discussing the source of conceptions of necessity). However, to deny that constraints are inherent in a particular form of life is not to deny that there are constraints on social life. See, e.g., id. at 195.

35. But that contexts and constraint can be remade does not mean that they can be changed all at once. "Inevitably, we must accept a conservative presumption." Passion, supra note 6, at 42 . Revolutionary reform is necessarily conservative, S. LoviBoND, supra note 11, at 109 ("[I]f we throw out too much of our intellectual furniture at once, we cease to have a habitable world-view . . ."), taking something as given, Social Theory, supra note 6 , at 18 , changing structures only piece by piece. See id. at 4, 158; False Necessity, supra note 3, at 4, 559 (only if proceed step by step); Ball, The City of Unger, 81 Nw. U.L. Rev. 625, 630 (1987) ("We can unbolt the pieces of our contexts and replace them one at a time."); $c f$. L. WITTGENSTEIN, ON CERTAINTY, supra note 11, II 343 ("We just can't investigate everything. . . . If I want the door to turn, the hinges must stay put.").

36. "At any given time we are largely the sum of our fundamental practices. But we are also the permanent possibility of revising them." PASSION, supra note 6, at 41 (emphasis in original); FalSE NeCESSITY, supra note 3, at 351 (same).

37. See, e.g., supra notes 29-36; Reconstructing, supra note 5, at 4 (constructing new form of power discourse); Social Justice, supra note 5, at 333 (constructing new form of liberal discourse); SoCial THEORY, supra note 6, at 148 ("approach allows for a piece-by-piece reconstruction of social frameworks."); Ackerman, Law, Economics, and the Problem of Legal Culture, 1986 DukE L.J. 929,946 (constructing new form of legal discourse). 


\section{CoNFLICT}

A theory of social meaning links Ackerman to Unger, Unger to Ackerman. But an aspect of that theory still divides: plasticity. While Unger exhorts us to "plastify" society by making its structures more easily transformed, Ackerman counsels us to resist. The scope of this conflict is explored below.

\section{A. Unger: Plasticity}

Social structures, Unger suggests, differ in at least two ways: They differ, first, in the content of the social world they induce, and second, in the ease with which they can be changed. ${ }^{38}$ Plasticity describes this latter dimension. A plastic society minimizes the difference between acting upon and acting within a social structure, ${ }^{39}$ "soften[ing] the distinction between quotidian revision within a context and revolutionary revision of the context itself . . .."40

The plasticity of a social structure, however, is not itself simply fixed or given; plasticity too can be changed. "We can alter not only the content but the quality of our routines, the sense in which they are routines at all." ${ }^{\prime \prime 1}$ By creating structures that multiply the instruments of challenge, ${ }^{42}$ social structures are transformed from rigid to plastic, expanding the opportunities to transcend and change formative contexts. ${ }^{43}$ Unger urges us to act upon this possibility, transforming the rigid into the pliant. ${ }^{44}$

38. Unger calls these dimensions "quality" and "content." See False NeCEssitry, supra note 3, at 4, 14; PAssion, supra note 6, at 192; Social Theory, supra note 6, at 4, 21, 156, 199.

39. See PAssion, supra note 6 , at 13 ("contrast between routine moves within a framework and revolutionary struggle about it loses its force").

40. Weinrib, Enduring Passion (Book Review), 94 YALE L.J. 1825, 1826 (1985). "Quotidian" describes the regular hectic sense of ordinary political conflict and change.

Plasticity does not by itself make a society unstable: "Rigidity is not stability, nor does the increased transparency and revisability of our practices mean we will want constantly to revise them." FaLSE NeCESSITY, supra note 3, at 280 . To the contrary, Unger suggests, plasticity means each individual revision is likely to be less dramatic than in a society where structural change has been less frequent. "The more a structure of thought . . . provides for the occasions and instruments of its own revision, the less you must choose between maintaining it and abandoning it for the sake of things it excludes." PAssion, supra note 6 , at 10 .

41. Passion, supra note 6, at 192; see also id. at 13 ("IT] vation an institutional form . . . becomes, the more perfectly it exemplifies the modernist ideal of a context so open to revision that the contrast between routine moves within a framework and revolutionary struggle about it loses its force.").

42. See False Necessity, supra note 3, at 87; PAssion, supra note 6, at 13, 192-93, 264.

43. Critical, supra note 6, at 94.

44. Unger at times suggests that the political program of plasticity is implied and warranted by the explanatory philosophy underlying his project. The philosophy or explanatory program is said to "inspire[l]" (Social. TheORY, supra note 6, at 5), "go[] hand in hand" (id. at 6), "teach[]" (id.), "logical[ly] or epistemological[ly] connect" (id. at 43), "lead directly" (id. at 3), have implications for (id. at 6, 159; PASSION, supra note 6, at 12; FALSE Necessity, supra note 3, at 37), stand closely connected (id. at 1, 19), "connect" (id. at 11), "secure" (id. at 12), "make[] room for" (id. at 253), justify (id. at 341), and "impl[y]" (id. at 571) the political program. But at other times Unger hedges on the link, claiming the theory "does not . . . determine" (id. at 578), can be separated from (id. at 173,305 ), and "does not depend upon" (id. at 253) the political program. Others have concluded the political recommendations are not compelled by the explanatory philosophy. See Boyle, supra note 6 , 
A number of independent grounds are offered for this injunction to plastify. Of these, only one-the special power plasticity promises democracy-is essential here. ${ }^{45}$

The promise of plasticity for democracy is this. By "diminishing the gap between framework-preserving and framework-transforming conflict," ${ }^{146}$ plastic structures are less entrenched, ${ }^{\mathbf{4 7}}$ more easily revised, "Less entrenched and more revisable [structures] help us empower ourselves individually and collectively." ${ }^{38}$ The more empowered a society, the greater the scope for democratic or collective action, and therefore, the greater its capacity to affirm the ends of democratic government. ${ }^{48}$ Plasticity is promoted, then, because it increases the capacity of a society to act democratically.

Unger promotes plasticity, and a familiar interpretation suggests that his patronage is unconditional. ${ }^{50}$ But before evaluating the scope of Unger's passion for plasticity, first contrast it with Ackerman's resistance.

\section{B. Ackerman: Dualism}

Like Unger, Ackerman recognizes social action both upon and within social structures, ${ }^{51}$ and would agree that a less entrenched, more plastic society could more easily revise social structures. He would disagree, however, with the notion that the mere fact a society can more easily change itself means that it can change itself more democratically.

It is this concern ${ }^{32}$-that any change be democratic change-that leads Ackerman to resist plasticity. Ackerman argues that plasticity, rather than empowering a democracy, decreases democratic control. ${ }^{53}$ For unless citi-

at 1076; Dunn, Unger's Politics and the Appraisal of Possibility, 81 Nw. U.L. Rev. 732, 738 (1987); Galston, False Universality: Infinite Personality and Finite Existence in Unger's Politics, $81 \mathrm{Nw.}$ U.L. Rev. 751, 758 (1987); Hawthorne, Practical Reason and Social Democracy, 81 Nw. U.L. REv. 766, 772 (1987); Isenbergh, Why Law?, 54 U. CHI. L. REv. 1117, 1118 (1987) (reviewing Critical).

45. Unger offers two other grounds for plasticity, both more evolutionary in their underpinnings. The first is tied to Unger's conception of personality. See Passion, supra note 6, at 95-271. The second is more pragmatic: Plasticity engenders progress, FALSE NECESSITY, supra note 3, at 578, by assuring the conditions for practical success, id. at 283; SocIAL ThEORY, supra note 6, at 5, 155, empowering a people or culture to adjust to the changing conditions of existence. For a historical analysis of the progress provided by plasticity, see PLASTICITY, supra note 6.

46. False Necessity, supra note 3, at 362.

47. SocIal THEORY, supra note 6 , at 154 ("The more entrenched a formative context, the greater the number of intermediate steps that must be traversed before context-preserving routines become context-transforming struggles.").

48. Id. at 5 .

49. As will be seen below, the desire to empower democratic government is shared by Ackerman and Unger. See Discovering, supra note 5, ch. 2 at 1 ("My aim is to provide the materials for a revised professional narrative which recognizes that the project of constitutional creation begun in Philadelphia continues onward to the present day."); infra text accompanying notes 51-74.

50. See infra note 114 .

51. See, e.g., Reconstructing, supta note 5, at 54 .

52. This is also a concern of others. See Ewald, supra note 6, at 733-53 (discussing suggestions of fascism in Unger); Galston, supra note 44 , at 759 .

53. See Ackerman, supra note 4, at 1038. In Ackerman's terms, a plastic constitutional structure 
zens keep a constant watch on the "everything up for grabs," point factions, ${ }^{\mathrm{bS}}$ rather than democrats, will manipulate social power. ${ }^{56}$ This fear of faction leads Ackerman to insist upon (some) rigidity for the constituting commitments of a democratic order. ${ }^{57}$

Ackerman's concern finds its clearest voice in his discussion of American democracy. ${ }^{\mathbf{5 8}}$ Drawing heavily upon a dualist theory of democracy, Ackerman distinguishes two kinds, or "tracks," of political action. The first track is the practice of normal politics; ordinary political decisions are made by representative institutions of government acting within existing structures. The second track is constitutional politics, where extraordinary decisions are made by popular bodies acting outside and upon the structures of ordinary government. ${ }^{6 \theta}$ Nothing on the first track can disrupt the second; ${ }^{60}$ action on the second track ${ }^{61}$ represents special moments of rare meaning, "when the American people do even more-when, after sustained debate and struggle, they hammer out new principles to guide public life." ${ }^{\prime 22}$

Dualism is a response to the democrat's desire to assure that changes in the fundamental principles of a constitutional structure represent the will of the people represented. Like Unger ${ }^{63}$ Ackerman's dualism responds to and builds upon a feature of the human condition: Citizens, dualism recognizes, ordinarily live for ends beyond the public good; each has her own private life, to which she devotes the majority of her effort. ${ }^{64}$ The constitu-

would be "single-tracked"; a rigid structure "dual-tracked." See infra notes 59-62 and accompanying text.

54. Sunstein, Routine and Revolution, 81 Nw. U.L. REv. 869, 871 (1987).

55. "By a faction I understand a number of citizens, whether amounting to a majority or minority of the whole, who are united and actuated by some common impulse of passion, or of interest, adverse to the rights of other citizens, or to the permanent and aggregate interests of the community." THE Federalist No. 10, at 78 (J. Madison) (C. Rossiter ed. 1961).

56. Ackerman, supra note 4 , at 1022 .

57. Id. at 1038.

Ackerman's resistance to plasticity is not so clearly pronounced in his other major works, such as SOCIAL JUSTICE IN THE LibERAL STATE, supra note 5 . But these works are distinct from the Storrs Lectures, supra note 4, and Discovering, supra note 5; the latter are disciplined more clearly by principles of democracy rather than of liberalism.

58. See Discovering, supra note 5; Ackerman, supra note 4.

59. See Ackerman, supra note 4, at 1039-44. The difference between these kinds of action translated into a difference in the value of each. See Discovering, supra note 5, ch. 2 at 9.

60. Ackerman, supra note 4, at 1039. But see PAssion, supra note 6, at 5 ("[T] $]$ he acts that reproduce these contexts, in changing circumstances, generate an endless stream of petty conflicts that may escalate at any moment into more fundamental, context-threatening disputes.").

61. Second track politics is, one hopes, characterized "by . . . appeals to the common good, ratified by a mobilized mass of American citizens expressing their assent through extraordinary institutional forms." Ackerman, supra note 4, at 1022 (citations omitted).

62. Id. at 1039; see also Discovering, supra note 5, ch. 2 at 50 ("[T]he Constitution cannot be understood without recognizing that Americans have, time and again, successfully repudiated large chunks of their past, and transformed their higher law to express deep changes in their political identities.").

63. See Passion, supra note 6.

64. See Ackerman, supra note 4, at 1032 (describing world "inhabited by men and women who gain their deepest satisfactions in activities far removed from the public forum."). 
tional democrat, therefore, cannot simply assume that public virtue ${ }^{65}$ will guide constitutional change, or that citizens will always focus their attention on the transformative process. Rather than assuming such attention, she must devise structures which engage these private citizens, ${ }^{68}$ assuring their participation, and assuring that their participation voices "considered judgment." "[Constitutional politics] . . . should be permitted to dominate the nation's life only during rare periods of heightened political consciousness." 68

By raising obstacles to structural revision, dualism assures that second track politics prevails only during times of heightened political consciousness. These obstacles raise the stakes for action upon fundamental structures of government, forcing ordinary government to turn outside itself, to the people, for constitutional change. ${ }^{68}$ This is the strategy of "differential sacrifice." Bo distinguishing ordinary political change from constitutional change, and making the latter more difficult to effect, dualism creates a vocabulary through which challenges to constitutional structures signal their own importance, ${ }^{71}$ and by so signaling, assure that any such change has the attention of private citizens.

In this way dualism addresses the imperfect ability of a democracy to assure that changes in its fundamental principles represent carefully deliberated and well understood transformations. All the well-known problems of democratic politics, articulated from Madison ${ }^{72}$ through modern political science, ${ }^{73}$ teach that not all change is representative change. These

65. See Ackerman, supra note 4, at 1031-33 (discussing dualism's economy of virtue).

66. See id. at 1032-43.

67. Id. at 1038 . The requirement of deliberation is not unproblematic; it has been extensively discussed by Professor Sunstein. See Sunstein, Naked Preferences and the Constitution, 84 Colum. L. Rev. 1689 (1984); Sunstein, Legal Interference with Private Preferences, 53 U. CHI. L. Rev. 1129 (1986).

68. Ackerman, supra note 4, at 1022. Cf. McCulloch v. Maryland, 17 U.S. (4 Wheat.) 316, 403 (1819) (The people "acted upon [the Constitution] in the only manner in which they can act safely, effectively, and wisely, on such a subject, by assembling in Convention.").

69. Ackerman, supra note 4, at 1051-57.

70. Id. at 1041. Differential sacrifice creates distinctions in meaning in much the same way that the institution of marriage constitutes different degrees of personal commitment. Id. The institution of marriage, like the institution of dualism, enables a stronger commitment than would otherwise exist. As with ordinary conflict within a marriage, ordinary conflict within a dualistic democracy can continue without drawing into question basic commitment to constitutional principles. As in marriage, when a challenge to constituting commitments is made, the challenge signals its own importance. As with the threat of divorce, the threat of constitutional change signals a change of importance, and engages the attention of its own citizens.

71. Cf. J. SeARLe, SPEECH ACTS 33-42 (1969) (describing constitutive rules, which create rather than merely regulate behavior they govern).

72. See ThE Federalist No. 48 (J. Madison) (discussing dangers of legislative usurpations).

Unger as well is cognizant of the concerns of faction. See Simon, Unger's Brazilian Journalism, 81 Nw. U.L. REv. 832, 855 (1987) ("[The constitutional] task . . . should be seen as laying ground rules for a process of 'permanent innovation.' The critical precondition for such a process is preventing the possibility that any particular class or faction assumes dominant power.").

73. See generally M. Olson, The Logic of Collective Action (1965). See also D. MaYhew, Congress: The Electoral Connection (1974) (using Olson-like analysis upon Congressional behavior). 
lessons lead Ackerman to resist treating ordinary and extra-ordinary politics alike. ${ }^{74}$

\section{Connection}

Unger and Ackerman disagree about whether plasticity should be endorsed; but this disagreement rests upon a confusion, engendered by an ambiguity within the meaning of transformation. Relying upon the understanding of social meaning discussed in Section I, this Section distinguishes between two notions of transformation. These notions relate differently to questions of democratic control: Whether plasticity is advanced should turn upon which sense of transformation is at issue.

\section{A. Translation and Alteration}

As discussed above, the meaning of a token is a function of the token and its context. ${ }^{75}$ As either token or context changes, meaning may change. ${ }^{76}$ If meaning is to be preserved, then, either (a) the changed element must be restored, or (b) the unchanged element must be transformed. Between context and token, assume that the token is generally more easily transformed. ${ }^{77}$ Where the context has changed, and the meaning of the token in the new context is different, then the meaning can be preserved by changing the token. ${ }^{78}$

74. Cf. Dunn, supra note 44, at 735 (drawing similar conclusions to resist plasticity, especially in "face of thermonuclear war").

75. See supra Section I.

76. Chief Justice Marshall made a similar point in McCulloch v. Maryland, 17 U.S. (4 Wheat.) 316,414 (1819): "Such is the character of human language, that no word conveys to the mind, in all situations, one single definite idea." (emphasis added).

77. The assumption is not required: $A$ counter-example is provided by United States v. Klein, 80 U.S. (13 Wall.) 128 (1872). Earlier lower-court rulings had held a pardon by President Johnson sufficient to show that a claimant was not a supporter of the Confederate rebellion. Congress attempted to change the meaning of that token by altering the rules of decision under which a loyalty oath and pardon were to be read. Under Congress' new rules, a pardon meant the claimant was a supporter of the rebellion. By changing the interpretative context, but for the act of the Court, Congress would have changed the meaning of the token of a pardon.

78. The change in the token can be a change in its words or in its application.

This does not imply that meaning can always be preserved. It is possible that the changes are such that the meaning of the token in the old context can no longer survive in the new. Consider Wittgenstein's example:

'It is as if our concepts involved a scaffolding of facts.' That would presumably mean: If you imagine certain facts otherwise, describe them otherwise, than the way they are, then you can no longer imagine the application of certain concepts, because the rules for their application have no analogue in the new circumstances. So what I am saying comes to this: A law is given for human beings, and a jurisprudent may well be capable of drawing consequences for any case that ordinarily comes his way; thus the law evidently has its use, makes sense. Nevertheless, its validity presupposes all sorts of things, and if the being that he is to judge is quite deviant from ordinary human beings, then e.g. the decision whether he has done a deed with evil intent will become not difficult but (simply) impossible.

L. WITTGENSTEIN, ZETTEL, supra note 11, at $\mathbb{1}$ 350. Justice Jackson made a similar point about the modality of translation in Northwestern Bands of Shoshone Indians v. United States:

We doubt if any interpreter could intelligently translate the contents of a writing that deals with the property concept, for the Indians did not have a word for it. People do not have words 
The following examples may help make this point clear.

A mime begs for dimes. A couple walks up, speaking English, and hands her a dime. She raises a sign saying "thanks." The token is "thanks;" the context includes the English-speaking couple handing her a dime. Another couple walks up, speaking German, and they too hand her a dime. Wanting to thank them as she thanked the couple before, she raises a different sign: "Danke." The token is different because the context is different as well. To do the same thing requires doing something different.

The point applies more generally. A diplomat is sent by her prime minister to offer another government "greetings." She is told to be polite; so after her meal in Iraq, ${ }^{79}$ she belches loudly. The next day, dining with the British Monarch, she wants to do as she had done before-namely, be polite. Therefore she bows graciously upon leaving. Once again, to do the same thing requires doing something different.

Both examples rehearse the obvious. But the point is equally valid in a less obvious context. A Workers' Compensation statute, written in 1901, sets the compensation for an injured finger at $\$ 25$. A worker injures her finger; a court awards $\$ 25$. In 1989 , faced with another similar loss, the court awards $\$ 2,500$. It reasons as follows: To do the same thing in this new context, it must award something other than $\$ 25$. By awarding $\$ 25$, the meaning of the award would be changed-again, because the context is so drastically different. The court, therefore, changes the token to compensate for the change in context. ${ }^{80}$

In each of these cases, the token is transformed to keep the meaning the same-a process we can label translation. Where meaning is not preserved, either because of a change in the context or token, the transformation effects an alteration. Transformations, therefore, are not all alike: Only some alter the meaning of the token transformed, while others translate the old meaning into a new context. ${ }^{81}$

to fit ideas that have never occurred to them. Ownership meant no more to them than to roam the land as a great common.

324 U.S. 335, 357 (1945) (Jackson, J., concurring). See also Tennessee v. Garner, 471 U.S. 1, 14 (1985) (White, J.) (pointing to failure of translation); cf. B. WhoRf, supra note 12, at 158 ("Certain ideas born of our own time-concept . . . would be . . impossible and devoid of meaning under [another] conception ....").

79. See D. Hawley, Manners and Correct Form in the Middle East 102 (1984).

80. This is not intended as a conclusive argument for ignoring the statutory sum: Statutes raise complicated issues far beyond the scope of this Note. For a complete discussion, including a similar example, see G. Calabresi, A Common LAw for the AGe of Statutes 40, 65-68 (1982) (discussing problems of indexing in statutory interpretation).

81. The notion of translation is not new to law. Consider, for example, Justice Jackson's opinion in Board of Educ. v. Barnette,

True, the task of translating the majestic generalities of the Bill of Rights, conceived as part of the pattern of liberal government in the eighteenth century, into concrete restraints on officials dealing with the problems of the twentieth century, is one to disturb self-confidence. These principles grew in soil which also produced a philosophy that the individual was the center of society, that his liberty was attainable through mere absence of governmental restraints, and 
This distinction between translation and alteration is critical to questions of democratic control. For if democratic endorsement tracks meaning rather than mere tokens or words, ${ }^{82}$ then a transformation that preserves the meaning of a democratically-endorsed token likewise preserves the democratic endorsement, while a transformation that alters the meaning destroys the endorsement. ${ }^{83}$

Only alteration, then, raises issues of democratic control; there is no reason, on democratic grounds, ${ }^{84}$ to oppose either translation or the plasticity that promotes translation. Translators can be plastic, and, since preserving of democratic control, democrats should insist upon it.

Whether we should accept Unger's exhortation to plastify, therefore,

that government should be entrusted with few controls and only the mildest supervision over men's affairs. We must transplant these rights to a soil in which the laissez-faire concept or principle of non-interference has withered at least as to economic affairs, and social advancements are increasingly sought through closer integration of society and through expanded and strengthened governmental controls.

319 U.S. 624, 639-40 (1943). A similar notion motivated Chief Justice Warren in Brown v. Board of Educ., 347 U.S. 483, 492 (1954) ("We must consider public education in the light of its full development and its present place in American life throughout the Nation."), and Justice Douglas in Bell v. Maryland, 378 U.S. 226, 255 (1964) (dissenting opinion) (because restaurants in modern context are as essential to interstate travel as inns and carriers, same principles should apply). See also City of Cleburne v. Cleburne Living Center, 105 S.Ct. 3249, 3269 (1985) ("Shifting cultural, political, and social patterns at times come to make past practices appear inconsistent with fundamental principles upon which American society rests . . . ."); Lassiter v. Department of Social Servs., 452 U.S. 18, 49 (1981) (Blackmun, J., dissenting) (discussing cases "establish[ing] rules translating due process in the welfare context"); Harris v. MCRae, 448 U.S. 297, 318 (1980) (denying that due process translates into affirmative funding obligation); id. at 348 (Marshall, J., dissenting) (claiming it does); School Dist. v. Schempp, 374 U.S. 203, 236 (1963) (Brennan, J., concurring) (translation in context of establishment clause cases); Evans v. Dutton, 400 F.2d 826, 829 (1968) (translation of due process into context of hearsay rule); Brest, The Misconceived Quest for the Original Understanding, 60 B.U.L. REv. 204, 218-21 (1980) (discussing translation of cruel and unusual punishment clause and death penalty); Gewirtz, Reverse Discrimination, NEw REPublic, Oct. 24, 1988, at 13, 15 ("[A] statute actually functions like an organism dropped into a broader sea of law, and it takes on coloration from its ever-changing environment. Its meaning can be modified indirectly . . . perhaps by other changes in the legal environment ....").

Translation has not, however, been universally endorsed. See Dred Scott v. Sandford, 60 U.S. (19 How.) 393,426 (1857) ("No one, we presume, supposes that any change in public opinion or feeling, in relation to this unfortunate race . . . should induce the court to give to the words of the Constitution a more liberal construction .... It is not only the same in words, but the same in meaning ...."). Chief Justice Taney ignores the possibility that the same words may give a different meaning, a possibility central to this Note.

82. One could say that democratic endorsement tracks the token rather than its meaning. Social choice models of legislation, viewing a statute as a bargain, envision such tracking. See generally Symposium on the Theory of Public Choice, 74 VA. L. REv. 167 (1988). Alternatively, one could argue that democratic endorsement tracks the "truth" of democratic principles. However, if tokens are properly translated, and if they originally represented the truth, then the translated token should represent the truth as well.

83. The fact that the endorsement of a token is transmitted says nothing about whether the meaning of the token still commands the support of a majority of the populace, which could very well have changed its mind. This Note assumes that a democratically-derived endorsement remains until removed, and that the mere shift in background conditions, requiring a translation, is not sufficient to effect a removal. $C$. The Federalist No. 78, at 470 (A. Hamilton) (C. Rossiter ed. 1961) (discussing constitutions) ("Until the people have, by some solemn and authoritative act, annulled or changed the established form, it is binding upon themselves collectively, as well as individually . . . .").

84. There may be institutional reasons to resist plasticity in translation, such as stare decisis, but these are beyond the scope of this Note. See CAlABRESI, supra note 80; Monaghan, Stare Decisis and Constitutional Adjudication, 88 ColvM. L. REv. 723 (1988). 
will turn upon the kind of transformation at issue-whether in context he promotes translation or alteration of democratically endorsed meaning.

\section{B. Unger's Rhetoric of Transformation}

Social life, Unger suggests, can be described by models of association, ${ }^{85}$ each comprised of "a group of ideals, . . . a set of practices that . . . stand for these ideals in fact; and an area of social experience to which the application of these principles remains confined."86 Using the terms of this Note, we can consider the area of social experience as the context, the practices or institutions as tokens, and the ideals as the meanings of the tokens within their context. A change in either the practice or the area of social experience can result in a change in the meaning or ideals of the model.

\section{Unger's Rhetoric of Alteration}

One kind of transformation urged by Unger is alteration: The practices of one model of association are applied in an area of social experience from which they were previously excluded, so as to change the ideals governing this area of social experience. ${ }^{87}$ The practices of democracy-equal franchise and majority voting, for example-are extended to the social experience of worker/management relations; the practices of the family are applied in the context of community relations. ${ }^{88}$ In both cases, the purpose of the application is to change the ideals within the new area of experience. When such applications succeed, the transformation is an alteration.

\section{Unger's Rhetoric of Translation}

However, the rhetoric of alteration is neither Unger's exclusive nor dominant rhetoric of transformation. Transformative action can change either the ideals or the practices, ${ }^{89}$ but between the two, "attack[s] on the ideals that inspire . . . a particular view of life" are the rarest. ${ }^{80}$ More often attacks are made upon the coherence of the practices of the model of

85. FALSE Necessity, supra note 3, at 101 ("Every extended practice of application of law demands recourse to tacit models of human association. The lawyer clears up the ambiguities of legal materials by referring to the basic principles that help organize and elucidate whole bodies of law.").

86. Id. at 104 (emphasis added).

87. "[W] hat began as a mere extension of familiar ideals into untried territory forces us in the end to refine and revise the ideal conceptions of human associations with which we had started." FALSE NECEssity, supra note 3 , at 105.

88. See, e.g., id. at 228 (discussing institutional changes to market economy to bring about petty commodity production).

89. "In each instance, the available options appeared to combine an abstract, indeterminate idea-of democratic rule, market decentralization, or technical coordination-with a concrete set of institutions that developed the idea in some directions rather than in others." SocIAL THEORY, supra note 6 , at 48 .

90. False Necessity, supra note 3, at 104. 
association, for it is here that "[m]ore often, the fit . . . comes apart." Where once the ideals and the practices cohered, they no longer do, and unless either the ideals or the practices are transformed, the pre-existing meaning will be lost. ${ }^{92}$ "[T]he perpetuation of [the practice] restrains the realization of its defining ideals . . . "93 A "partial adjustment[]"94 is required, responding to "changes in circumstances"95 to restore the model to its original purpose.

This is no longer the rhetoric of alteration. Indeed, the process Unger describes here is a paradigmatic example of translation. A token (here an institution or practice) is changed to adjust for a change in the context (changed circumstances) so as to maintain its meaning (ideals). The transformation effects a translation: Rather than altering, translation preserves meaning from one context to another. To the extent this occurs "more often," to the extent Unger argues for "partial adjustments," and to the extent such partiality is required for stability, ${ }^{98}$ Unger's transformations manifest the rhetoric of translation..$^{97}$

Two very different rhetorics, then, animate Unger's project. Only the rhetoric of alteration raises the issues of democratic control motivating Ackerman's project of dualism. To the extent Unger argues for plasticity in translation, his rhetoric is helpful, ${ }^{98}$ but not wildly controversial. ${ }^{99}$ Any dispute over plasticity, then, will lie in the domain of transformations that alter rather than translate.

91. Id. at 105 .

92. Cf. Sunstein, supra note 54 , at $883-84$ (intentions of a practice will not be met unless institutions changed).

93. FAise Necessity, supra note 3, at 27.

94. Id. at 280 .

95. Id. at 552; see also Plastrcity, supra note 6, at 153 (defining plasticity as "the facility with which work relations among people . . . can be constantly shifted in order to suit changing circumstances, resources and intentions.") (emphasis added).

Unger explicitly notes the possibility of changes in the formative context being translations, or "functional equivalents." False Necessity, supra note 3, at 65. The point, however, is left undeveloped.

96. The plastic society, Unger suggests, is stable. FALSE NECESSrTY, supra note 3, at 280 ("[L]ess entrenched structures are by definition more open to revision ... . [b]ut they are not therefore more unstable . . . ."). Instability is risked only when cultures divide over abstract ideals; when the "conflicting partisan visions get translated into the detailed schemes of collective life," $i d$. at 280 , however, the risk of wildly divergent views is erased.

97. Many of the ideas Unger articulates in describing a constitutional democracy are understandable as translations of 18 th Century counterparts into 20 th Century circumstances. See FaLSE NeCESSITY, supra note 3, at 456-57 (discussing principles governing conflict of powers); id. at 227 ("The constitutional techniques for limiting government power must not be restricted to the armory of eighteenth-century institutional devices that control government only by disabling it from ambitious reform."); id. at 449 (increased Madisonian conflict necessary to translate checks and balances to modern activist state.).

98. Unger's critique of "false necessity," see supra text accompanying notes 33-35, as an explanation of the rigidity in democratic politics is particularly useful. To the extent this rigidity rests upon "superstition," Socral TheORY, stupra note 6, at 4, and this superstition explains an unwillingness to translate, the critique is useful even to one who wants no alteration of existing structures at all. $C f$. FALSE NECESSITY, supra note 3, at 305 ("It is true that you do not need to share an allegiance to the radical project in order to evaluate or even accept these descriptive and explanatory ideas.").

99. See supra note 81 . 


\section{G. Ackerman's Rhetorics of Transformation}

Like Unger, Ackerman distinguishes alteration from translation. But only in the context of alteration does Ackerman resist plasticity. In the context of translation, specifically constitutional interpretation, Ackerman both endorses and relies upon plasticity. Sketching these two rhetorics in Ackerman will reveal the distance remaining between Ackerman and Unger.

\section{Ackerman's Rhetoric of Alteration}

Ackerman focuses upon three "moments" of constitutional change in American political history, each a fundamental alteration in constitutional meaning. The first moment, the founding of the Constitution, involved a fundamental change in the ideal of sovereignty; ${ }^{100}$ the second, after the Civil War, a change in the ideal of equality and national government; ${ }^{101}$ and the third, during the New Deal, establishment of the "legitimacy of the activist welfare state." ${ }^{\mathbf{1 0 2}}$ In each case, the transformations involved a change in the character of the Constitution. Each was a paradigmatic example of alteration rather than translation.

These changes were effected only after great political struggle; struggles which, given the generally perceived desirability of each, may seem regrettable. Ackerman, however, applauds the structures that required the struggle, for the act of surmounting the barriers to constitutional change gave special meaning to the resulting structures. ${ }^{103}$ The dualistic barriers imposed on democracy served democratic ends-rigidity to assure that any change has the attention and endorsement of the people.

\section{Ackerman's Rhetoric of Translation}

For the same reason that dualism resists plasticity in alteration, dualism embraces translation. In its aim to give full effect to constitutional meaning, dualism requires an ongoing process of interpretative synthesis. ${ }^{104}$ This exercise of hermeneutic understanding necessarily incorporates the notion of translation sketched above. ${ }^{105}$ Dualism requires translation where translation preserves democratic meaning.

100. See G. Wood, The Creation of the American Republic: 1776-1787 430-564 (1969); Amar, Of Sovereignty and Federalism, 96 YALE L.J. 1425, 1439-51 (1987).

101. See Ackerman, supra note 4, at 1065-69.

102. Id. at 1053. See also id. at 1056 ("IJ]udges recognized that a new constitutional principle had indeed been ratified") (emphasis added).

103. The high cost to second track lawmaking constitutes its own worth: "If it were cheap and easy for higher lawmaking to succeed, we would be debasing the remarkable collective achievement involved when millions of Americans do manage . . . to engage in an act of self-government . . . ." Ackerman, supra note 4, at 1043.

104. Ackerman, supra note 4 , at 1071-72.

105. See Brest, supra note 81 , at 218 (discussing the "hermeneutical problems" of the interpreter, linking hermeneutics and translation by pointing to need to " translate' the adopters' concepts and 
The very structure of Ackerman's articulation of dualism, moreover, reveals this reliance on translation. To establish the legitimacy of the substantive constitutional changes effected in each constitutional moment, Ackerman must defend the problematic procedures by which the Constitution was altered. ${ }^{108}$ For in none of the three moments was the Constitution amended by formalistically correct constitutional means. ${ }^{107}$ Yet despite these formal failings, these amendments bear the full weight of constitutional law. How can such failings be ignored?

Note that Article V itself is a meaning token. An amendment, therefore, can fall outside the specific terms of Article V, but remain within its meaning. ${ }^{108}$ This possibility can be relied upon in Ackerman's claim that the processes through which the Constitution was amended in the Givil War and New Deal eras were "functional[ly] similar[]"109 to the process imagined by Article V: Each process, though different, had the same meaning. A change in constitutional circumstances (changes of context) required a change in the application of Article $\mathrm{V}$ (the token) to maintain the meaning of the Article $V$ procedure. ${ }^{110}$

It is irrelevant whether one agrees with Ackerman's conception of the amending processes, or with his view that either moment proceeded under a functional equivalent to Article V. What is important here is that Ackerman has acknowledged changes in the token of Article V so as to preserve its meaning. Despite the strictures of dualist democracy, Ackerman has allowed a translation of Article $\mathrm{V}$ where translation preserved Article V's meaning.

\section{Translation, Alteration, and Plasticity}

We are now able to reassess the differences between Ackerman and Unger. By distinguishing between the rhetorics of alteration and translation, substantial grounds for agreement between Ackerman and Unger are revealed.

\section{Plasticity and Translation}

On democratic grounds, Ackerman resists plasticity. But such resistance should not extend to transformations that translate. Translation transmits

intentions into our time"); Tushnet, Following the Rules Laid Down, 96 HaRv. L. REv. 781, 798-804 (1983) (discussing hermeneutic practice of interpretation).

106. See Ackerman, supra note 4, at 1051-72.

107. The founding was "plainly illegal" under the Articles of Confederation, Ackerman, supra note 4, at 1058; but see Amar, supra note 3, at 1047-48; the Civil War amendments violated the terms of Article V, Ackerman, supra note 4,1065-69; and the New Deal was accomplished wholly outside the literal terms of Article V, id. at 1069.

108. And conversely, an amendment could fall within the precise terms of Article $V$, but outside its meaning.

109. Discovering, supra note 5 , ch. 1 at 30 .

110. Id., ch. 1 at 25 . 
the democratic endorsement of the tokens it transforms, ${ }^{111}$ and therefore cannot be rejected on democratic grounds. ${ }^{112}$

Accordingly, Ackerman does not resist translations of Article V, even though the transformation of the amending procedure was not itself democratically-endorsed. More generally, neither should he resist transformations that translate, or structures that foster such translation.

\section{Plasticity and Alteration}

Plasticity in alteration raises other concerns; among them Ackerman's apprehensions for democratic control. A democracy must assure that changes reflect a democratic will; plasticity's failure to provide such an assurance ${ }^{113}$ drives Ackerman to promote dualism. Ackerman apparently conditions plasticity, while Unger apparently does not. ${ }^{114}$

If the dispute between Ackerman and Unger distills to a dispute over the reach of plasticity in alteration, then it is not clear that wide disagreement remains. Unger's injunction to plastify is never unconditional. ${ }^{115}$ Plasticity is limited by pragmatic, prudential concerns. One reading of these concerns might well support dualism's limitations in the context of constitutional commitments.

Unger offers two express limitations on plasticity. One limitation is poverty; where poverty exists, plasticity may be deferred. ${ }^{116}$ But poverty is a wider concept than mere economic deprivation, and it is an analogous poverty-political poverty-that leads Ackerman to dualism. Like economic poverty, political poverty diverts democrats from the affairs of the state. A politically impoverished nation must erect mechanisms to assure that any fundamental change gains the attention of the people. Whatever its cause, poverty, whether economic or political, must limit the scope of plasticity in alteration.

Unger's second limit upon plasticity, however, in the realm of personal

111. See supra text accompanying notes $75-84$.

112. Although again, there may be other institutional grounds for limiting plasticity, such as stare decisis. See supra note 84.

113. See Sunstein, supra note 54 , at 870,892 . But see FAtSE NeCEsSITY, supra note 3, at 369 ("Governmental power must not be exclusively and permanently exercised by such a sector of the population nor used for its primary benefit.").

114. For the best examples of this interpretation, see Ewald, supra note 6, at 738 ("Just as a series of one-night stands does not add up to a worthwhile personal relationship . . . so a series of disruptions by the Bureau of Liquification does not add up to a worthwhile scheme of human association."); Herzog, Rummaging Through the Emperor's Wardrobe, $86 \mathrm{MICH}$. L. REv. 1434, 1444 (1988) ("Unger does seem bent on change for its own sake.") (reviewing PourTIcs); Holmes, The Professor of Smashing: The preposterous political romanticism of Roberto Unger, NEw REPUBLIC, Oct. 19, 1987, at 30, 31 ("Unger still hopes to do for the daylight what Sade did for the night.") (reviewing same); Yack, Towards a Free Marketplace of Social Institutions, 101 Harv. L. Rev. $1961,1976-77$ (1988) ("[T]hey can engage in [constructive] . . . tasks only if they are willing to abandon Unger's futile pursuit of non-constraining constraints.") (reviewing same).

115. See, e.g., FALSE Necessity, supra note 3, at 461 ("There are limits to the extent to which any particular set of institutional arrangements can embody a principle of permanent self-revision.").

116. Social Theory, supra note 6 , at 210 . 
relations, is even more illuminating. Consider Unger's treatment of marriage:

Even within the realm of personal encounter, the commitment to this repeated hazard of self-transformation does not always imply a willingness to destabilize all attachments. It all depends. Thus, for example, one reason to view a marriage as indissoluble is that this commitment enables husband and wife to accept and experience conflict without fearing every disagreement as a possible cause of separation. ${ }^{117}$

Here Unger opens wide the possible grounds for limits on plasticity. As in the realm of personal relations, precommitment in the political realm can be enabling ${ }^{118}$ rather than restrictive. Depending upon what "it all depends" on, plasticity in constitutional politics could be similarly restricted: For the same reasons plasticity should be limited in the domain of constituting personal commitments, so, too, could it be limited in the domain of constituting social or political commitments.

Both limits on plasticity suggested by Unger, then, arguably support, in the context of constitutional politics, the limits of dualism suggested by Ackerman.

\section{CONCLUSION}

Many have read Unger's injunction to plastify as an unequivocal command to radical and constant revolution in every domain of social experience. ${ }^{118}$ This Note has argued that it is not: The transformation that plasticity brings does not inevitably imply a change in social or political meaning, nor is the injunction to plastify unlimited. Transformations either alter or preserve the meaning of a democratic token, and even where transformation alters, Unger offers us grounds for limiting the scope of plasticity.

The apparent gulf, then, between Ackerman and Unger has been

117. PASsion, supra note 6, at 267 (emphasis added). For a discussion of Unger's limitation on plasticity in marriage, see Holmes, supra note 114, at 321; Note, Roberto Unger's Theory of Personality, Law and Society, 55 U. CIN. L. REv. 423, 444 (1986). Compare Unger's limitation with Ackerman's, supra note 70. For an example of the tendency to ignore Unger's discussion of "enabling" commitment, see Herzog, supra note 114, at 1442 (claiming Unger always views institutions as constraining, "never enabling").

118. Cf. Galston, supra note 44 , at 762 ("some revision-resisting contexts actually liberate us."); Sunstein, supra note 54, at 889-90 (discussing precommitment as facilitative).

119. See, e.g., Sunstein, supra note 54, at 871 ("For Unger, the overriding purpose of a revised system of institutional arrangements is to ensure that fundamental issues should be continually "up for grabs.' The system should be structured to facilitate its frequent and fundamental revision. The distinction between routine and revolution should be eliminated; checks and balances should disappear. Massive transformations should be easy to accomplish."); id. at 881 ("The 'empowered democracy' . . is a departure from all the traditional understandings."); Holmes, supra note 114, at 31 (viewing Unger as context-smashing for its own sake); Isenbergh, supra note 44 , at 1119 ("It is a defining element of radical movements to tear down the world before building it anew."). 
crossed. On democratic grounds, Ackerman has no reason to refuse plasticity in translation; on grounds internal to his own argument, Unger may have reason to limit plasticity in alteration in the constitutional context. By distinguishing the sense of transformation that is the focus of each, the gap dividing them has been diminished, even if not completely closed.

Differences in attitude remain, and these differences are not easily catalogued. Rather than attempting such an index, this Note offers a different reading of the radical rhetoric of the intellectual father of Critical Legal Studies. This reading suggests not only that there is more to plasticity than may at first appear, but also that plasticity is less radical than is so often claimed. Plasticity may help preserve constitutional meaning in the face of contextual change, and, when employed to effect constitutional change, nothing requires that it be unlimited.

In this way, plasticity may be less radical than some would suggest; but in speaking less radically, it perhaps says something more. 